\title{
Agreeing to Disagree: The European Union and the United Kingdom after Brexit
}

\author{
Kieran Bradley*
}

Brexit - Withdrawal Agreement - Article 50 TEU - Negotiations - Legal character of agreement - Transition period - 'New legal order' - 'Due regard' - ECJ jurisdiction - Governance - Enforcement and supervision - Dispute settlement Future relations

\section{INTRODUCTION}

\section{'This is not a Withdrawal Agreement'}

The first thing to know about the 'Withdrawal Agreement' between the EU and the UK is that it is not, as its name might imply, a legal instrument whereby the EU agrees to the withdrawal of the UK from its polity. ${ }^{1}$ In this, it differs from an 'accession agreement', by which a third State agrees with the member states to accede to the Union, or an 'association agreement', whereby a third State agrees to establish with the Union 'an association involving reciprocal rights and obligations, common action and special procedures'. ${ }^{2}$ The EU had no power to agree, or disagree, with the UK's decision to withdraw; as the Court of Justice noted in Wightman, " $\mathrm{t}$ ] he decision to withdraw is for [a] Member State alone to take, in accordance with its constitutional requirements, and therefore depends solely on

*Former judge of the EU Civil Service Tribunal, former Special Adviser to the CJEU on Brexit. Best thanks are due to Laurence Helfer for providing information on international practice regarding withdrawal from treaties, and to Graham Butler, Michael Dougan, Brendan O'Leary, Marie Simonsen and the editors for their very helpful comments on an earlier version of the text; the usual disclaimer applies.

${ }^{1}$ OJ 2020 L 29/7; for convenience, the term '[Withdrawal] Agreement' will nonetheless be used throughout.

${ }^{2}$ Respectively Arts. 49 TEU and 217 TFEU.

European Constitutional Law Review, 16: 379-416, 2020

(C) The Author(s), 2020. Published by Cambridge University Presss on behalf of European Constitutional Law Review. This is an Open Access article, distributed under the terms of the Creative Commons Attribution licence (http://creativecommons.org/licenses/by/4.0/), which permits unrestricted re-use, distribution, and reproduction in any medium, provided the original work is properly cited. doi: $10.1017 / S 1574019620000231$ 
its sovereign choice'. ${ }^{3}$ Subject only to the slim possibility of a member state's unilaterally revoking its notification of intention to leave, withdrawal follows ineluctably by operation of Article 50(3) TEU. This provides that ' $[t]$ he Treaties shall cease to apply' to the member state concerned either on the date specified by the Withdrawal Agreement or, failing the conclusion of any such agreement, two years from the date of the notification of its intention to withdraw; the time limit can be extended by agreement between the Union and the state concerned. The act in question is therefore an 'Agreement on the Withdrawal' of the UK from the Union, which sets out 'the arrangements for [the] withdrawal', albeit that the agreement must 'take account of the framework of [the withdrawing State's] future relationship with the Union'.

\section{'No deal is better than a bad deal for Britain'}

According to their respective rhetorical stances, and regardless of the likely hard economic realities, one of the parties to the Brexit negotiations had a significantly greater interest in concluding a withdrawal agreement than the other. The Union wished to protect the interests of those of its citizens who had in good faith used their Treaty rights to move and settle in the UK, to fill the hole in its finances created by UK withdrawal, and to limit as far as possible the impact of withdrawal, and the overnight creation of an new external border of the Union, on the island of Ireland. In order to keep the withdrawal process orderly, it wished to establish transitional arrangements, and institute efficient political and legal structures, where feasible as close as possible to its own highly successful models, or at least to familiar models employed in other contexts. None of these objectives could have been achieved without an agreement within the relevant deadline.

Conversely, the Conservative government has demonstrated a lukewarm regard at best for EU citizens resident in its territory, until their 'utility' was strikingly demonstrated during the coronavirus pandemic, prompting Boris Johnson to extend to one national group the irresistible invitation 'come back, tutti benvenuti. ${ }^{4}$ Whether EU27 citizens are 'benvenuti' or not, the Union had good reason to consider that the June 2016 referendum was to a significant extent won on the promise of limiting immigration from the EU. A similar lack of empathy applies to UK nationals resident abroad, a good many of whom are disenfranchised, ${ }^{5}$ and were thus ignored in the Brexit debate, referendum, and subsequent

${ }^{3}$ ECJ 10 December 2018, Case C-621/18, Andy Wightman and Others v Secretary of State for Exiting the European Union, EU:C:2018:999, para. 50.

${ }^{4}$ Press conference, 3 June 2020.

${ }^{5}$ See e.g. Court of Appeal for England and Wales 20 May 2016, Shindler \& Another v Chancellor of the Duchy of Lancaster \& Another [2016] EWCA Civ 469. 
general elections. The Prime Minister, Theresa May, set the tone in her keynote speech to the party faithful in October 2016, with her chilling remark that if you believe you are a citizen of the world, you are a citizen of nowhere'. ${ }^{6}$

Under a withdrawal agreement of any kind, the UK would have been obliged to settle its financial debts towards the Union, even though it was advised by the House of Lords European Union Committee it could avoid doing in the case of a 'no deal' exit. ${ }^{7}$ On one occasion, the Foreign Secretary concurred in the House of Commons with an MP who suggested that the UK should refuse to make any payments to the Union after Brexit. ${ }^{8}$ The government was also aware that it would probably have to accept a degree of post-Brexit supervision at the hands of the Court of Justice of the European Union, which has the status of a pantomime villain in the raddled imagination of sections of the British political community. Finally, in order to avoid a 'hard border' between the two parts of the island of Ireland and to respect the Good Friday/Belfast Agreement of 1998, Northern Ireland would have to be granted some form of special status, whether in the Union's customs union or the single market or both, which risked creating the impression in some minds that the UK will be somehow less 'united' as a result of the Withdrawal Agreement.

Repeated British threats to walk away from the proposed agreement right up to the last minute could therefore be seen as not simply negotiation posturing or institutional petulance, but the logical reflection of the government's policy that 'no deal is better than a bad deal for Britain', combined with its own evaluation or, in the views of some, gross underestimation of the economic, social and political repercussions of withdrawal without an agreement. The Withdrawal Agreement might be considered a mere precursor to a further agreement, or series of agreements, defining the scope and nature of the future links between the Union and the UK, the prospect of which should in principle have provided an incentive for the UK to stay at the table. The parties are not even ad idem on the name of any future instrument(s), still less its/their possible content. In British parlance, it would be a 'free trade agreement', often identified as being equivalent to an existing Union agreement accompanied by one or more plusses while, in accordance with the terminology of Article $50 \mathrm{TEU}$, for the Union it is to be an agreement on the 'future relationship' of the two parties.

${ }^{6}$ See e.g. 〈www.bbc.com/news/uk-politics-37788717〉, visited 13 October 2020.

${ }^{7}$ House of Lords European Union Committee, Brexit and the EU Budget, $15^{\text {th }}$ Report of Session 2016-2017, HL Paper 125 (HMSO 2017).

${ }^{8}$ Boris Johnson, replying to Philip Hollobone, Hansard HC Deb, vol 627, 11 July 2017.

${ }^{9}$ On the former, see for example the widely-reported remarks of David Frost at the ULB, Brussels, on 17 February 2020. On the latter, see European Commission, Recommendation for a Council Decision authorising the opening of negotiations for a new partnership with the United Kingdom of Great Britain and Northern Ireland, COM (2020) 35 final, Brussels, 3 February 2020. 


\section{An agreement to disagree: overview}

The fundamental disagreement of the parties concerned the desirability of continued UK membership of the Union. They also disagreed on such matters as the withdrawal procedure, the principle of UK indebtedness towards the Union, and the future role of the Court of Justice in the context of their relations, right down to trivia such as the correct title of the transition period. In this regard, the Withdrawal Agreement may be seen as more an agreement to disagree than the product of a true meeting of minds to give effect to a common objective, though of course the text only sets out matters on which consensus has in the end been reached. Thus, for example, the Court is only allowed a rather truncated role in dispute resolution, despite the UK's spontaneous recognition that the Court 'aims to provide both consistent interpretation of EU law ... and a clear process for dispute resolution when disagreements arise' or, more succinctly, provides 'an effective remedy from a judicial body'. ${ }^{10}$ Though beyond the scope of the present article, the contrasting perspectives of the parties may also reassert themselves in disputes regarding the application of the Agreement and the accompanying political declaration. Just three weeks after the Agreement had entered into force, it was reported that Prime Minister Boris Johnson was seeking a way to 'get around' the Ireland/Northern Ireland Protocol; the government has also refused the Union's request to establish a permanent office in Belfast, a volte-face which has been widely criticised as 'petty'. ${ }^{11}$

While formally a single instrument, the Agreement regulates a number of matters of very different legal character, and according to a range of time scales. Part Two, for example, concerns the acquisition and legal protection of rights of individuals and members of their family, in particular residence rights and access to certain social security benefits; beneficiaries (including citizens yet to be born) may in principle enjoy these rights for their lifetime, provided they remain within the scope of application of the Agreement. Part Three, the so-called 'Separation Provisions', on the other hand, regulates a wide variety of legal situations governed by Union law which are still ongoing at the moment the UK's withdrawal becomes fully effective on 1 January 2021. These situations primarily involve Union companies and legal persons doing business with the UK, and vice versa, as well certain individuals who have legal procedures outstanding: 'EU law continue[s] to apply if the transaction began before the end of the

${ }^{10}$ The United Kingdom's exit from and new partnership with the European Union, Cm 9147 (HMSO, 2 February 2017), hereinafter the 'Brexit White Paper', para. 2.3, p. 13, and para. A.20, Annex A, p. 72; see also 'Supervision, enforcement, and dispute settlement', below.

${ }^{11}$ See respectively the controversy regarding the 2020 Internal Market Bill and Irish Times, 3 May 2020. 
transition period'. ${ }^{12}$ Though the application of these provisions is not time limited, they do not apply (other than exceptionally) to situations which did not exist, or procedures which had not commenced, at the end of the transition period, and should therefore diminish in relevance quite rapidly in the coming years.

Part Five governs financial relations between the Union and the UK on the international law plane; it lays down provisions on the calculation of the UK's future payments to the Union budget and its financial entitlements. A number of its provisions regulate the financial entitlements of natural or legal persons, which is why the Court of Justice is vested with jurisdiction to review the application of this Part by means of requests for preliminary rulings, as well as infringement and enforcement actions. While not formally subject to a temporal limitation either, its scope of application will shrink over time as the respective financial obligations of the parties are exhausted. The core of Part Four is time; it establishes a transition period which expires at midnight (Brussels time) on 31 December 2020. Meantime Part Four affects all those who come within the scope of Union law, including in principle a large number of third countries with which the Union has formal relations.

Parts One and Six (respectively 'Common Provisions' and 'Institutional and Final Provisions') provide the overarching legal framework for the Agreement; they apply to all those persons and entities who are affected by the other four parts of the Agreement, for as long as the Agreement itself lasts, or perhaps beyond, if certain of its provisions are carried over to a future agreement.

The main body of the Agreement is complemented by Protocols on Ireland/ Northern Ireland, the UK Sovereign Bases in Cyprus, and Gibraltar, and nine annexes, though not, oddly enough, a table of contents. While the Agreement came into force at midnight on 31 January 2020, many of its provisions, and in particular those of Parts Two, Three, and some of Parts Five and Six, will only apply from the end of the transition period, that is, from 1 January 2021. ${ }^{13}$

Unlike many modern international agreements, there is no explanatory report for the Withdrawal Agreement. Instead, there are several preparatory draft texts, and publicly available statements of position of the protagonists. ${ }^{14}$ Whether they

\footnotetext{
${ }^{12}$ P Craig, 'Brexit a Drama: The Endgame - Part I', European Law Review (2020) Oxford Legal Studies Research Paper No.10/2020, 〈papers.ssrn.com/sol3/papers.cfm?abstract_id=3541896), visited 13 October 2020, p. 4.

${ }^{13} \mathrm{See}$ 'The transition period' below.

${ }^{14}$ See 〈ec.europa.eu/commission/brexit-negotiations/negotiating-documents-article-50-negotiationsunited-kingdom_en $\rangle$ and /www.gov.uk/government/organisations/department-for-exiting-the-europeanunion $\rangle$, both visited 13 October 2020 .
} 
amount to a useful legislative history for the purposes of interpreting the Agreement, a technique only embraced recently by the Court of Justice, ${ }^{15}$ remains to be seen.

\section{Structure of the present article}

The present article will examine the Withdrawal Agreement essentially from the perspective of the EU legal order; the impact of Brexit on the constitution of the UK has already engendered a wealth of academic literature, which will presumably be extended to embrace the Withdrawal Agreement in due course. ${ }^{16}$ The following matters will be considered: the legal background to the agreement, the negotiations, the legal character of the Agreement, the transition period, the legal order of the Withdrawal Agreement, the jurisdiction of the Court of Justice, governance provisions, and supervision, enforcement, and dispute settlement. A number of necessarily rather provisional remarks are offered by way of conclusions.

\section{LEGAL BACKGROUND}

\section{The genesis of Article 50 TEU}

In proposing a 'Constitution for Europe', the European Convention of 20022003 included a provision establishing once and for all that a Member State has a right unilaterally to withdraw from the new improved EU. The matter had long been subject to debate. The preponderance of legal opinion was against the existence of any such right, though it was also suggested at the time that the Union would have been wise not to block the exit of a Member State which wished to withdraw, as two Member States had contemplated doing in the mid-1970s and early 1980s. ${ }^{17}$ For others, including certain of the authors of the text on which the Convention provision was based, a prerogative of unilateral withdrawal 'was widely presumed to exist well before' it was reflected in Union

${ }^{15}$ See notably ECJ 27 November 2012, Pringle EU:C:2012:756, para. 135, and Wightman, supra n. 3, para. 68, and K. Lenaerts and J. Gutierrez-Fons, To Say What the Law of the EU Is: Methods of Interpretation and the European Court of Justice, AEL Working Papers 2013/9, p. 19-24.

${ }^{16}$ See e.g. M. Gordon, 'Brexit: a Challenge for the UK Constitution, of the UK Constitution', 12 EUConst (2016) p. 409; M. Dougan (ed.), The UK after Brexit (Intersentia 2017); and F. Fabbrini (ed.), The Law and Politics of Brexit (Oxford University Press 2017) chs. 5 to 7.

${ }^{17} \mathrm{~J}$ Weiler, 'Alternatives to Withdrawal from and International Organisation: The Case of the European Economic Community', 20 Israeli Law Review (1985) p. 282, and J. Hill, 'The European Economic Community: The Right of Member State Withdrawal', 12(3) Georgia Journal of International and Comparative Law (1982) p. 335. 
law. ${ }^{18}$ The Convention provision subsequently became Article 50 TEU, which expressly recognises a right for a Member State unilaterally to withdraw, without indicating whether the right pre-existed Article $50 \mathrm{TEU}$ or was granted thereby; in relevant part, it reads '[a]ny Member State may decide to withdraw from the Union in accordance with its own constitutional requirements'.

\section{The referendum and the triggering of the withdrawal procedure}

One of the multiple pretenders to authorship of Article 50 TEU, ${ }^{19}$ Giuliano Amato, was reported to have claimed that this provision had been included 'to prevent the British government complaining that there was no way for them to leave the [Union]' ${ }^{20}$ It is perhaps fitting then that the UK should be the first Member State to invoke this provision. It did so as a result of a would-be consultative referendum held on 23 June 2016, though many commentators have deplored the polarised and singularly under-informative character of the referendum campaign by the partisans of both 'Leave' and 'Remain'. ${ }^{21}$ While the turnout for the vote was considerable, the margin of victory of the Leave camp was slim, particularly for a policy choice with such momentous consequences. Moreover, Scotland, Northern Ireland, London, and many other major English cities all voted Remain, some by healthy margins, but Leave nonetheless carried the day. ${ }^{22}$

Having gone down to defeat in the referendum, the UK government sought to by-pass Parliament and trigger the withdrawal procedure by relying on executive powers in the area of international relations. The Supreme Court of the UK put paid to that, ${ }^{23}$ though Parliament did not in the end hinder, or even delay, the

\footnotetext{
${ }^{18}$ M. Dougan, 'So Long, Farewell, Auf Wiedersehen, Goodbye: The UK's Withdrawal Package', 57 CMLRev (2020) p. 631 at p. 632.

${ }^{19}$ See, for example, R Schütze, European Union Law, $2^{\text {nd }}$ edn. (Cambridge University Press 2018) p. $855-856$.

${ }^{20} \mathrm{G}$. Amato, Independent, 26 July 2016. He also described Brexit as 'a disaster' and called David Cameron 'mad' for calling the referendum, 〈www.independent.co.uk/news/uk/politics/brexit-eureferendum-britain-theresa-may-article-50-not-supposed-meant-to-be-used-trigger-giuliano-a7156656. html , visited 13 October 2020.

${ }^{21}$ See e.g. D. Gowland, Britain and the European Union (Routledge 2017) p. 345-346.

${ }^{22}$ Manchester, Leeds, Liverpool and Bristol all voted Remain: BBC News online, EU Referendum: The Result in Maps and Charts, 24 June 2016.

${ }^{23} R$ (Miller) v Secretary of State for Exiting the European Union [2017] UKSC 5 ('Miller P); for a nuanced evaluation, see C. McCrudden and D. Halberstam, 'Miller and Northern Ireland: A Critical Constitutional Response', Queen's University Belfast Law Research Paper No. 2018-3.
} 
lodging of the notification of intention to withdraw. ${ }^{24}$ The government then called a snap general election which saw its majority evaporate, and the balance of power handed to the Democratic Unionist Party of Northern Ireland, whose leadership often appeared to be seriously out of step with the majority of voters in that part of the UK, possibly including many of its own.

On the Union side, leaders of Union institutions and national governments expressed their regret at the result of the referendum, and the hope that the UK would change its mind. ${ }^{25}$ Three and a half years later, on the other hand, it was suggested that many in Brussels were feeling a "good riddance" form of relief ... though spoken quietly and behind closed doors: good riddance to Britain, often accompanied by "de Gaulle was right after all"”. ${ }^{26}$

\section{Legal basis and material scope of the agreement}

Article 50(2) TEU provides the legal foundation for the agreement and identifies its scope, that is, 'arrangements for [the] withdrawal' of the Member State in question. The agreement is also required to 'tak[e] account of the framework of [the withdrawing State's] future relationship with the Union'. While each of these two acts has its own importance, the scope of application of the Withdrawal Agreement, both materially and temporally, is in principle much narrower than any agreement, or other instrument, defining the future relationship. The latter potentially covers the entire gamut of the Union's activities not already regulated and should define if, and to what extent, it will maintain relations with the withdrawing State in these areas, while the former only regulates a number of priority issues, and establishes the governance structures to 'enable ... withdrawal to take place in an orderly fashion'. ${ }^{27}$

Though deferred in time, the exercise of the right to withdraw is essentially untrammelled by any substantive conditions, such as a duty to maintain, take account of, or even consider, legal situations which had been created on the basis of the Treaty and on which withdrawal would have a negative impact, or a requirement that the withdrawing Member State settle its financial obligations; in the case of the Union, this latter mean essentially financial obligations contracted by the Union on behalf of all the Member States. The procedural

\footnotetext{
${ }^{24}$ European Union (Notification of Withdrawal) Act 2017; the Prime Minister, Theresa May, did however wait until the somewhat muted celebrations for the $60^{\text {th }}$ anniversary of the signing of the Treaties of Rome on 25 March were over.

${ }^{25}$ See e.g. PoliticsHome, 16 January 2018, 〈www.politicshome.com/news/article/juncker-andtusk-britain-could-still-change-its-mind-on-brexit $\rangle$, visited 13 October 2020.

${ }^{26}$ J.H.H. Weiler, 'Brexit - Apportioning the Blame', EJIL:Talk!, 17 April 2020, 〈www.ejiltalk. org/brexit-apportioning-the-blame/ $\rangle$, visited 13 October 2020.

${ }^{27}$ Wightman, supra n. 3, para. 56.
} 
conditions foreseen in the Treaties for withdrawal are scant: compliance by the Member State concerned with its own constitutional requirements and notification to the Union of its intention to withdraw, a good faith attempt by the parties to reach an agreement on an orderly withdrawal, and, where no agreement is reached, an obligation on the notifying State to wait out a two-year period before withdrawing. While the Court of Justice drew a parallel between Article 50 TEU and the withdrawal provisions of the 1969 Vienna Convention on the Law of Treaties ${ }^{28}$ on one view the scheme of the Union provisions gives an exorbitant importance to the interests of the withdrawing State over those of the Union, in marked contrast to those of the Vienna Convention which are more balanced. ${ }^{29}$

\section{Negotiating the Agreement}

\section{The political context: asymmetric hostility}

The negotiations on the Withdrawal Agreement were conducted in an atmosphere of asymmetric political hostility, that is, hostility on the part of the UK government and its allies, and factions of the opposition parties in Westminster, that was not, or not apparently, reciprocated by the EU, which acted throughout more in sorrow than in anger. Unless the Union positively wished to see a particular Member State withdraw, this is only to be expected in a certain measure. In that respect too the Withdrawal Agreement is quite different from accession and association agreements, where the third States and the Union are at least formally well disposed towards each other, and are keen to improve their trading arrangements and political ties, rather than casting these off. The Agreement is therefore concerned with defining the conditions under which certain rights and obligations are maintained and enforced in a situation where they are otherwise liable to disappear completely, or whose enforcement is liable to be rendered excessively difficult if not legally impossible. In effect, the parties have quite different, even opposing, general objectives: the Union sought to preserve as much as possible of the existing framework of relations with the UK as defined by the Union Treaties, or at least to minimise the consequences of the inevitable disruption of withdrawal, while the government's declared goal was to throw off the shackles of EU dominion and 'take back control', while maintaining only such trading opportunities as suited its economic operators.

\footnotetext{
${ }^{28}$ Wightman, supra n. 3, paras. 70 and 71.

${ }^{29}$ K. Bradley, 'Disintegration through Law: Brexit, Article 50 and the Court', in C. Kilpatrick and J. Scott (eds.), Contemporary Challenges to EU Legality (Oxford University Press forthcoming) sections 3 and 7.
} 


\section{The negotiation procedure: 'time's wingèd chariot'}

The negotiation procedure followed in the case of withdrawal agreements, which is only laid down in the most skeletal of terms in Article 50(2) TEU, is highly unusual. The Commission, in the person of Michel Barnier and his team, took the lead on behalf of the Union; though afforded no formal role in this process, the member states (via the Council and/or European Council), and the European Parliament (whose consent for the final agreement was required) were kept well informed of progress, and were regularly given the opportunity of commenting on Commission proposals on the principal subjects for discussion. ${ }^{30}$ From the moment the referendum results were known, the UK was put in a state of purdah by the Union institutions, a policy known by the distinctly un-catchy slogan 'no negotiation without notification'; in fact, this self-denying ordinance was not so much about negotiation as discouraging contacts between the institutions and the UK on any matter concerning Brexit, in order to avoid any risk of divide et impera. The Commission's adoption of this policy was challenged before the General Court, though the case was eventually withdrawn. ${ }^{31} \mathrm{Mr}$ Barnier used the 'phoney war' period from 24 June 2016 to 29 March 2017 inter alia to brief representatives of the 27 remaining Member States, and the major Union institutions, on different aspects of the planned agreement. For her part, Prime Minister Theresa May set out, in her Lancaster House speech of 17 January 2017, a list of objectives the government aimed to achieve through the Brexit process, which were explained in more detail in a White Paper of 2 February $2017 .{ }^{32}$

The official notification on 29 March 2017 by the UK of its intention to withdraw from the Union started the clock ticking on the two-year time limit. Precisely a month later, the European Council adopted its 'Guidelines' on both the material contents of the agreement and the Union's approach to defining the framework of its future relations with the Union. ${ }^{33}$ On the eve of the meeting, the President of the European Council, Donald Tusk, summarised the Union's priorities as being 'people, money, and Ireland', ${ }^{34}$ which is a pithy, if obviously incomplete, summary of the material scope of the agreement eventually concluded. As regards procedure, the Union indicated that it would only start examining the possible framework for its future relations with the UK when the

\footnotetext{
${ }^{30}$ Dougan, supra n. 18, section 2.1.1, p. 634-637.

${ }^{31}$ General Court Case T-713/16, Fair deal for expats and Others v Commission OJ 2016 C $428 / 20$.

${ }^{32}$ Brexit White Paper, supra n. 10.

${ }^{33}$ Guidelines of 29 April 2017 (the 'European Council Guidelines'), EUCO XT 20004/17, para. 6, p. 5.

${ }^{34}$ Independent, 28 April 2017.
} 
European Council decides that sufficient progress has been made in the first phase towards reaching a satisfactory agreement' on withdrawal, an approach quickly dubbed 'sequencing'. ${ }^{35}$

This insistence prompted a bellicose riposte from the Secretary of State for Exiting the European Union, David Davis, who promised in mid-May 2017 that the timetable for Brexit talks would be 'the row of the summer'. ${ }^{36}$ While this particular row did not in the end materialise, the UK government held on doggedly to the notion of an 'implementation period', including in its relevant domestic legislation, where it is downgraded for some purposes to an undignified 'IP'. ${ }^{37}$

\section{Conduct of the negotiations}

It would be difficult to overestimate the importance of the temporal constraint of Article 50(3) TEU in the conduct of the negotiations, even if the UK requested, and was granted, three extensions of the time limit. Before negotiations commenced, two years was widely considered too brief a period during which to agree on the unravelling of almost half a century of close integration between the UK and its Union partners. As it transpired, the negotiators were able to produce an agreed draft legal text within 20 months, though this was in part due to the extraordinary delay of nine months between the referendum and the notification of intention to withdraw.

Negotiations proper commenced in June 2017 and were conducted in line with the Union's views on transparency; the parties each published 'position papers' and, in the case of the UK, 'partnership papers' and 'technical notes', on the major topics for discussions. By 8 December 2017, the negotiators were able to present the European Council with a joint report on progress during the first phase of negotiations; ${ }^{38}$ this allowed the move to the second phase, that is, 'an overall understanding on the framework for the future relationship. ${ }^{39} \mathrm{~A}$ first draft of the Withdrawal Agreement in legal form followed on 19 March 2018; this was colour coded to distinguish between the provisions on which the parties were fully in agreement (green), those which reflected an agreement in principle subject to linguistic modifications (yellow), and those on which negotiations were still

\footnotetext{
${ }^{35}$ European Council Guidelines, supra n. 33, para. 5, p. 4; originally borrowed from the science of genetics, the term is in common usage in the context of WTO dispute resolution.

${ }^{36}$ Financial Times, 14 May 2017.

${ }^{37}$ European Union (Withdrawal Agreement) Act 2020, s. 39(1)(h) and (2)-(5); see 'The transition period', below.

${ }^{38}$ TF50 (2017) 19, 〈ec.europa.eu/commission/sites/beta-political/files/joint_report.pdf $\rangle$, visited 13 October 2020.

${ }^{39}$ European Council Guidelines, supra n 33, para. 5, p. 4.
} 
ongoing (without colouring). ${ }^{40}$ On 14 November 2018, agreement was reached on the text of a full Withdrawal Agreement, which famously boasted 585 A4 pages, as well as a political declaration on the framework for the future relations between the Union and the UK. ${ }^{41}$ This Agreement was, however, subsequently rejected by the House of Commons on three occasions. Under Boris Johnson, who became Prime Minister in July 2019, the government negotiated a revised Protocol on Ireland and a revised political declaration in October 2019. Following another general election in December 2019, which Johnson won handsomely with the slogan 'Get Brexit done', the amended agreement was approved by the House of Commons on 9 January 2020, signed on 24 January, concluded by the EU on 30 January, and came into force the following day at midnight. ${ }^{42}$ The Union and the UK also agreed on a revised political declaration. ${ }^{43}$

\section{The legal character of the Withdrawal Agreement}

\section{The Withdrawal Agreement: one of a kind}

The Withdrawal Agreement is unique in the constellation of legal acts by which the Union seeks to achieve its policy objectives. This is not because the Treaty provides a specific procedure for the negotiation and conclusion of the agreement, which differs in certain respects from the normal procedure which applies for international agreements; this is true too of commercial policy and association agreements, while accession agreements are in fact concluded by the Member States, not the Union, and the acceding State. ${ }^{44}$ Nor is it so because one of the contracting parties is a Member State; the Union may conclude, for example, headquarters agreements with the host Member State at the seat or working place of different institutions and agencies. ${ }^{45}$ Instead, the Withdrawal Agreement is

${ }^{40}$ See $\langle$ www.gov.uk/government/publications/draft-withdrawal-agreement-19-march-2018〉, visited 13 October 2020.

${ }^{41} \mathrm{See}$ 〈ec.europa.eu/commission/publications/draft-agreement-withdrawal-uk-eu-agreed-negotiatorslevel-14-november-2018-including-text-article-132-text-subject-final-legal-revision-coming-days_en $\rangle$, visited 13 October 2020.

${ }^{42}$ The withdrawal took effect at $11 \mathrm{pm}$ UK time; see also the author's op-ed of 26 February 2020 on EU Law Live, 〈eulawlive.com/op-ed-oh-to-be-in-england-now-that-brexits-there-somepersonal-literary-reflections-by-kieran-bradley/ $/$, visited 13 October 2020.

${ }^{43} \mathrm{OJ} 2020$ C 34/1.

${ }^{44}$ Respectively Arts. 218, 207, and 217 TFEU; see also J. Heliskoski, 'The Procedural Law of International Agreements: A Thematic Journey through Article TFEU', 57 CMLRev (2020) p. 79, and P. Polak, 'EU Withdrawal Law After Brexit: The Emergence of a Unique Legal Procedure', in J Santos Vara et al. (eds.), The Routledge Handbook on the International Dimension of Brexit (Routledge forthcoming).

${ }^{45}$ See e.g. ECJ 8 December 2005, Case C-220/03, ECB v Germany, EU:C:2005:748. 
unique because of its hybrid legal character. At the time of its negotiation and conclusion, it is not 'an agreement with one or more third countries or international organisations', which is the definition of international agreement under Union law, ${ }^{46}$ but rather an act of Union law, adopted by the Union and a Member State on the basis of the Treaty. On coming into force, however, it metamorphoses into an international agreement between the Union and a third State, which is subject to interpretation according to the canons of interpretation of international law. ${ }^{47}$

The Withdrawal Agreement is almost certainly unique in the annals of international relations too. In general, a 'short, stylized letter of two or three paragraphs' to the depository of a treaty is sufficient; ${ }^{48}$ for example, South Africa's notification of withdrawal from the Rome Statute on the International Criminal Court, which is no banal political act, runs to some three pages, while the Trump administration's reasons for withdrawing from the Trans-Pacific Partnership occupy just three paragraphs. In the absence of a specific exit clause, the 1969 Vienna Convention on the Law of Treaties requires both the notification of intention to withdraw and the subsequent instrument of withdrawal to be in writing, but does not envisage, still less require, a formal agreement. ${ }^{49}$

\section{An Article 218(11) TFEU opinion on the draft withdrawal agreement?}

The hybrid character of the agreement created one conundrum which the Court of Justice was not in the end required to resolve: would the Court have jurisdiction to provide an Opinion on the basis of Article 218(11) TFEU on a draft withdrawal agreement? Under this provision, the Court may rule ex ante on whether 'an agreement envisaged is compatible with the Treaties'; notwithstanding its designation, the so-called 'Opinion' is fully binding in law, and an adverse Opinion requires either the agreement or the Treaties to be amended. ${ }^{50}$ Article 218 TFEU purports to lay down the procedure for the negotiation and conclusion of 'international agreements', though not agreements between the Union and one or other Member State.

In a handful of landmark cases, the Court has bypassed the constraints which arise from a literal reading of its jurisdictional clauses, where it considered this was

${ }^{46}$ Art. 216(1) TFEU.

${ }^{47}$ ECJ 6 December 2001, Opinion 2/00, Cartagena Protocol, EU:C:2001:664, para. 24.

${ }^{48}$ See L. Helfer, 'Exiting Treaties', 91 Virginia Law Review (2005) p. 1579 at p. 1598.

${ }^{49}$ Arts. 65-68, esp. Art. 67(1) and (2), 1969 Vienna Convention on the Law of Treaties; see also Bradley, supra n. 29, section 3.

${ }^{50}$ See generally G. Butler, 'Pre-Ratification Judicial Review of International Agreements to be Concluded by the European Union', in M. Derlén and J. Lindholm, The Court of Justice of the European Union - Multidisciplinary Perspectives (Hart Publishing 2018) p. 53. 
necessary in order to pursue its Treaty duty to 'ensure that in the interpretation and application of the Treaties the law is observed', most famously to allow the European Parliament directly to defend its then rather meagre prerogatives in the Union's legislative process. ${ }^{51}$ The purpose of the Opinion procedure is 'to forestall complications which would result from legal disputes concerning the compatibility with the Treaty of international agreements binding on the [Union]'; an adverse Opinion on an agreement already concluded 'could not fail to provoke, not only in the Union context but also in that of international relations, serious difficulties and might give rise to adverse consequences for all interested parties, including third countries'. ${ }^{52}$ In the present case, large parts of the agreement affected immediately the legal situation of individuals and businesses (residence rights, financial arrangements, the Irish border question), in some cases irrevocably, ${ }^{53}$ while other parts have a limited and rather brief shelf-life, where an ex post judicial interpretation might be of limited practical utility. It could be argued that if ever there was an agreement which merited ex ante review, it is a withdrawal agreement.

On only one occasion has the Court not provided an Opinion which had been requested, where the agreement at issue was adopted some months after the request had been lodged. There the Court held that 'the preventive intent of [Article 218(11) TFEU] can no longer be achieved if the Court rules on an agreement which has already been concluded'.$^{54}$ If provided in good time an Opinion on an envisaged withdrawal agreement could be said to promote such preventive effect, if the Court were willing to depart from the literal interpretation of the relevant provisions.

\section{THE TRANSITION PERIOD}

\section{Objectives of the transition period: between 'political purgatory' and a 'cliff-edge'}

Even before negotiations started on the agreement, the UK had floated the idea of a bridging period following formal withdrawal during which it would have a special legal status. While rejecting 'some sort of unlimited transitional status, in which we find ourselves stuck forever in some kind of permanent political purgatory', the Prime Minister, Theresa May, acknowledged the need to avoid

\footnotetext{
${ }^{51}$ Art. 19(1), $1^{\text {st }}$ subpara., TEU; see notably ECJ 23 April 1986, Case 296/83, Les Verts v European Parliament, EU:C:1986:166, and ECJ 22 May 1990, Case C-70/88, European Parliament v Council, EU:C:1990:217.

${ }^{52}$ ECJ 13 December 1995, Opinion 3/94, Agreement on Bananas, EU:C:1995:436, para. 16.

${ }^{53} \mathrm{See}$ 'Institutional exclusion of the United Kingdom' below.

${ }^{54}$ Opinion 3/94, supra n. 52, para. 19.
} 
'a cliff-edge for business or a threat to stability'. She proposed that an agreement on the future relationship between the UK and the Union be concluded within the two years earmarked for the conclusion of the withdrawal agreement; this could include a 'phased process of implementation ... [which] would give businesses enough time to plan and prepare for those new arrangements'. ${ }^{55}$ However, this proposal ran up against an objection in principle and one practical impediment. Given that after withdrawal the UK would be a third State, it was considered legally impossible to initiate the negotiation procedure at a point in time when the UK was in fact still a Member State; in any case, Article 50(2) TEU only provided for the establishment of a 'framework for future relations', rather than an agreement, which would require another legal basis. It was also widely considered unrealistic to attempt to negotiate and conclude such an agreement at a time when the energies of both parties were concentrated on an agreement for an orderly withdrawal, a caution which proved to be amply justified.

It has been suggested that the institution of a transition period would allow the government a temporal disconnect between exit and its practical consequences 'sufficient to establish a plausible deniability that any negative impacts upon the UK should actually be attributed to leaving the EU'. ${ }^{56}$ In the result, the brevity of the transition period, and the government's refusal even to contemplate an extension of that period, however, would significantly diminish any such effect.

For its part, the European Council had clearer ideas of the utility of any transitional arrangements: it was 'to provide for bridges towards the foreseeable framework for the future relationship in the light of the progress made' and 'must be clearly defined, limited in time, and subject to effective enforcement mechanism'. The temporary extension of the Union acquis would be subject to the application of the full panoply of 'Union regulatory, budgetary, supervisory, judiciary and enforcements mechanisms and structures'. ${ }^{57}$

\section{Substantive provisions on transition}

Part Four of the Agreement, comprising just seven articles, provides for a 'transition or implementation period', ${ }^{58}$ starting on 1 February 2020 and ending on 31 December 2020. Originally intended to last 21 months, with the different

\footnotetext{
${ }^{55}$ Lancaster House speech, 17 January 2017, 〈www.gov.uk/government/speeches/thegovernments-negotiating-objectives-for-exiting-the-eu-pm-speech $\rangle$.

${ }^{56}$ Dougan, supra n. 18, p. 663.

${ }^{57}$ European Council Guidelines, supra n. 33, para. 6, p. 5.

${ }^{58}$ Art. 126 Withdrawal Agreement; the term 'implementation' is quietly omitted from the remainder of the text.
} 
postponements of the coming into effect of the UK's withdrawal, it was whittled down to just 11 months. Up until 1 July 2020, the parties could have agreed to a single extension of the transition period 'for up to 1 or 2 years'. ${ }^{59}$ It is clear from Article 132(2)(c) of the Agreement that an extension for number of months which is not a multiple of 12 would be possible. In any case, the question quickly became moot, as the day before the Withdrawal Agreement was signed any such extension was rendered illegal as a matter of UK law. ${ }^{60}$ It has been suggested that it might be possible for the parties to decide after 1 July 2020 to extend the transition period, notwithstanding the seemingly clear terms of Article 132 of the Agreement. ${ }^{61}$

During this period, Union law applies to and in the UK, where it must be given 'the same legal effects as those which it produces within the Union and its Member States', including as regards its interpretation and application, for all the world as if the UK were still a Member State. ${ }^{62}$ There are, however, some exceptions to this general rule. UK nationals, for example, may not participate in citizens' initiatives, and no longer enjoy the right under Union law to vote in local elections. The UK may not participate during this period in any enhanced cooperation, or any permanent structured cooperation as of right, nor have access to 'security-related sensitive information' in the context of information exchange initiatives. ${ }^{63}$

At the same time, the UK is bound to comply with any international obligations contracted by the Union, including under agreements concluded by the Member States acting on the Union's behalf, or by the Union and its Member States acting jointly. ${ }^{64}$ A footnote to Article 129(1) of the Agreement blithely informs the reader that ' $[t]$ he Union will notify other parties to these agreements that during the transition period the United Kingdom is to be treated as a Member State'; a model 'note verbale' was duly published on the Commission's website. ${ }^{65}$ Also in the field of external relations, the UK is explicitly enjoined during the transition period from taking 'any action or initiative which is

${ }^{59}$ Art. 132(1) Withdrawal Agreement.

${ }^{60}$ European Union (Withdrawal Agreement) Act 2020, s. 33.

${ }^{61}$ See e.g. R. Repassi, 'Avoiding the Next Brexit Cliff-Edge: Extending the Transition Period for the UK after 1 July 2020', EU Law Analysis, 30 January 2020, 〈eulawanalysis.blogspot.com/2020/ 01/avoiding-next-brexit-cliff-edge.html , and for a more reserved view, see C. Barnard, 'Can the Brexit transition period still be extended', 30 June 2020 〈ukandeu.ac.uk/can-the-brexittransition-period-still-be-extended/ $/$, both visited 13 October 2020.

${ }^{62}$ Art. $127(1), 1^{\text {st }}$ subpara., and (3) WA.

${ }^{63}$ Art. $127(4)$ and (7) Withdrawal Agreement.

${ }^{64}$ Art. $129(1)$ Withdrawal Agreement.

${ }^{65} \mathrm{See}$ <ec.europa.eu/commission/sites/beta-political/files/template-note-verbale-internationalpartners-after-signature-withdrawal-agreement.pdf $\rangle$, visited 13 October 2020. 
likely to be prejudicial to the Union's interests, in particular in the framework of any international organisation, agency, conference or forum of which the United Kingdom is a party in its own right'; in return, it is entitled to negotiate, sign and ratify any international agreements in the domain of exclusive Union competence, on condition they do not enter into force without the Union's authorisation. ${ }^{66}$ The Council decision of 30 January 2020 concluding the Withdrawal Agreement lays down a number of conditions, substantive and procedural, for the granting of such authorisations. ${ }^{67}$

While bound in principle by any Council decisions on common security and defence policy, the UK may 'in exceptional cases' declare that for 'vital and stated reasons of national policy' it will not apply a particular decision. ${ }^{68}$ Those with long memories will recognise the criterion for resorting to this exemption as having been inspired by the Luxembourg Compromise of 1966 which hamstrung the then European Community's policy-making process for more than two decades.

\section{Institutional exclusion of the UK}

The most significant exception to the rule treating the UK as a Member State during this period is the exclusion of its representatives, appointees, and nominees from participation in the work of the Union's institutions and other bodies, including any bodies set up under international agreements to which the Union is party. Thus, for example, the UK government will not be allowed to exercise the right of initiative recognised to Member States under the Treaties, and the Westminster Parliament, though informed of initiatives for Union legislation, will not be able to exercise the prerogatives of the national parliaments, notably in respect of subsidiarity control. ${ }^{69}$ This institutional ostracism is not, however, complete; UK representatives and experts may 'exceptionally' be invited to participate, though not vote, in meetings of the relevant committees, groups, or 'other similar entities', including Union agencies. The conditions of such participation are designed to ensure the presence of UK representatives is limited to what

${ }^{66}$ Art. 129(1), (3) and (4) Withdrawal Agreement. Prior to withdrawal, the Union could in any case have authorised the UK to act in the sphere of the Union's exclusive competences under Art. 2(1) TFEU; K. Bradley, 'On the Cusp: Brexit and Public International Law', in I. Govaere and S. Garben, The Interface between EU and International Law (Hart Publishing 2019) p. 203 at p. 212-217.

${ }^{67}$ Art. 3, Council Decision (EU) 2020/135, OJ L 29/1; see generally Santos Vara et al., supra n. 44 .

${ }^{68}$ Art. $129(6)$ Withdrawal Agreement.

${ }^{69}$ Protocol No 2 to the TFEU on the application of the principles of subsidiarity and proportionality; see e.g. K. Bradley, 'Legislating in the European Union', in C Barnard and S. Peers, European Union Law, $3^{\text {rd }}$ edn (Oxford University Press 2020) section 5, p. 117-123. 
is strictly necessary, and that it is 'in the interest of the Union, in particular for the effective implementation of Union law during the transition period'.$^{70}$

The exclusion of UK members of the institutions, and the cessation of the recruitment of British nationals as members of staff of the Union institutions and bodies, took effect from 1 February $2020 .^{71}$ Though bound by Union law in the transition period, the UK does not participate directly in policy-making or Union supervision of the activities of the Member States, including for this purpose the UK itself. Given the long lead-time for much Union legislation, at least an important proportion of the instruments adopted during the transition period will not apply to the UK in any case, ${ }^{72}$ and its exclusion from the policy institutions appears not to have given rise to any major objections from the UK side.

Some have argued that different considerations apply as regards the Court of Justice of the European Union, ${ }^{73}$ whose jurisdiction will include both disputes concerning facts which arose when the UK was still a Member State, and certain disputes initiated subsequently. On the one hand, it is obvious that judges of the Court, whose independence must be 'beyond doubt', ${ }^{74}$ cannot be said to 'represent' their Member State, the way a minister, for example, represents their Member State in the Council. On the other hand, in many transnational courts where the bench hearing a case does not contain a national of the defendant Member State, that State will have the possibility to appoint an ad hoc national judge, so that the matter will not be judged exclusively by 'foreign judges' ${ }^{75}$ While it is true that no party may insist on the presence on the bench of a judge of a particular nationality in the case of the Court of Justice, ${ }^{76}$ it is also true that that court is comprised of 'one judge from each Member State', ${ }^{77}$ and that all the members of the Court are given the opportunity to discuss any case which comes before the Court at its weekly general meeting. At one point, the UK hinted in a somewhat elliptical fashion that it might be open to considering the possibility of

\footnotetext{
${ }^{70}$ Article 128(5) Withdrawal Agreement.

${ }^{71} 8^{\text {th }}$ paragraph in the preamble to the Agreement, and Article 7(1)(a) and (c) Withdrawal Agreement; see also $4^{\text {th }}$ para in the preamble to Council Decision (EU) 2020/135 on the conclusion of the Withdrawal Agreement OJ 2020 L 20/1 31 January 2020.

${ }^{72}$ This was also true of at least part of the legislation adopted in the twilight period between notification and exit, though the Treaty did not provide for its exclusion then, except as regards the withdrawal process itself (Art. 50(4) TEU).

${ }^{73}$ For the human interest angle on the abrupt retirement of a judge, see J. Rozenberg, 'What's next for the EU's British judges?', Law Society Gazette, 17 February 2020.

${ }^{74}$ Art. 19(2), $3^{\text {rd }}$ subpara. TEU.

${ }^{75} \mathrm{C}$. Tomuschat, 'National Representation of Judges and Legitimacy of International Jurisdictions: Lessons from ICJ to ECJ?', in I. Pernice et al. (eds.), The Future of the European Judicial System in a Comparative Perspective (Nomos 2006) p. 183-190.

${ }^{76}$ Art. $18,4^{\text {th }}$ para, Statute of the Court of Justice of the European Union.

${ }^{77}$ Art. 19(2), $1^{\text {st }}$ subpara., TEU.
} 
maintaining its judicial personnel at the Court 'for any period during which pending cases are to be resolved', though the Union negotiators reportedly rejected this suggestion which was not taken up in any of the joint texts of the negotiators or the parties. ${ }^{78}$ Given the Court's working methods, such judges or Advocate General would in any case only very exceptionally have been sitting on proceedings directly involving the UK.

There remains the question of the Advocate General nominated by the UK. The last incumbent unsuccessfully took annulment proceedings against the decision to remove her from office and to gift the nomination to her post to the Greek government. ${ }^{79}$

\section{The law of the Withdrawal Agreement}

\section{$A$ 'new legal order of international law'?}

Under the Withdrawal Agreement, EU law is applied, as a matter of public international law, to a non-Member State, which is in turn required to give effect to Union law by means of its domestic primary legislation. The Agreement is not unique in this regard; the EEA Agreement, for example, gave rise to a similar construction, though the EEA legal order included the establishment of autonomous supervisory and judicial organs for the three EFTA States which are members of the EEA, as well as a Joint Committee for political decision-making by the parties. ${ }^{80}$

The Withdrawal Agreement is primarily applied and supervised in the respective territories of the parties by their own competent authorities, though there are a few exceptions, such as the Joint Committees and specialised committees, the arbitration panel, and the possible intervention of the Court of Justice at the behest of the panel. ${ }^{81}$ Though largely of limited duration, this new legal creation is in principle still incomplete, in that it may be complemented by a wider agreement on the future relations between the Union and the UK.

The intention of the Agreement is broadly speaking that the Agreement, and those provisions of Union law which it applies 'in respect of and in the United Kingdom' shall be applied as if the UK were still a Member State. ${ }^{82}$ 'Union law' is

\footnotetext{
${ }^{78}$ Respectively HM Government, Ongoing Union judicial and administrative proceedings (July 2017) para. 9, p. 2, and 'Brexit: UK fails to retain voice in European court of justice', The Guardian, 7 December 2017.

${ }^{79}$ Cases T- 180/20 and T-550/20, Sharpston $\mathrm{v}$ Council and Conference of the Representatives of the Governments of the Member States, and T-184/20, Sharpston v Court of Justice of the European Union, rejected by Orders of 6 October 2020, EU:T:2020:473, EU:T:2020:474 and EU:T:2020:474.

${ }^{80}$ See generally C. Baudenbacher (ed.), The Handbook of EEA Law (Springer 2016).

${ }^{81}$ See 'Supervision, enforcement and dispute settlement' below.

${ }^{82}$ Art. 4(1) Withdrawal Agreement.
} 
defined widely, including, for example, general principles of Union law, the acts of the institutions, and 'declarations made in the context of intergovernmental conferences, ${ }^{83}$ The inclusion of declarations might seem surprising, given their denomination, and the fact that many of these are issued unilaterally by a single Member State or group of Member States. It may be that, depending on their content and compatibility with the Treaties, they are intended to be accorded a higher legal status than declarations adopted during the legislative process, which 'cannot be used for the purposes of interpreting a provision of secondary legislation where ... no reference is made to the content of the declaration in the wording of the provision in question. ${ }^{84}$

The relevant provisions of the Agreement and Union law are to have 'the same legal effects as those which they produce within the Union and its Members States', including direct effect where the necessary conditions are fulfilled, and primacy over inconsistent or incompatible domestic provisions; they are to be interpreted and applied 'in accordance with the methods and general principles of Union law'. ${ }^{85}$ The Union and the UK are bound by mutual duties of sincere cooperation; references to Union provisions include amendments to, or replacements of, those provisions, as need be, and, subject to listed exceptions, references to the 'Member States' and their authorities are taken to include the UK and its authorities. ${ }^{86}$ With just a few notable exceptions, Union law provisions are those which applied on the last day of the transition period (31 December 2020), including any amendments or replacements which came into effect before then. ${ }^{87}$ The exceptions include social security regulations under Part Two of the Agreement, and Union provisions referred to in the Protocols on Ireland and Cyprus. ${ }^{88}$

It might at first blush seem slightly ironic that Articles 2 and 4 of the Agreement provide a more complete and explicit description respectively of the material scope and the fundamental characteristics of Union law than are to be found in the text of the Treaties. This feature of the Agreement reflects the development over time of the techniques and sources of Union law, and the central role played by the Court's case law in teasing out these characteristics. Even after the Lisbon reforms, the Treaties do not mention the term 'direct effect' of Treaty provisions, and relegate the concept of primacy to an obscure declaration annexed to the Treaties quoting an opinion of the legal service of one of the

\footnotetext{
${ }^{83}$ Art. 2(a) Withdrawal Agreement.

${ }^{84}$ ECJ 26 February 1991, Case C-292/89, Antonissen, EU:C:1991:80, para. 18.

${ }^{85}$ Art. 4(1)-(3) Withdrawal Agreement.

${ }^{86}$ Arts. 5 and 7 Withdrawal Agreement.

${ }^{87}$ Art. 6 Withdrawal Agreement.

${ }^{88}$ Respectively Art. 36 Withdrawal Agreement, Art. 13(3) Protocol on Ireland/Northern Ireland, and Art. 1(4) Protocol on Cyprus.
} 
institutions. ${ }^{89}$ However, as the UK has just turned its back on the Union and its legal order, dotting the 'i's and crossing the 't's may be justified after all.

\section{Post-Brexit Union case law in the UK: the vexed question of 'due regard'}

Decisions of the Court of Justice squarely fall within Union law as part of the 'acts of the institutions'. Given that the Agreement applies provisions of Union law on an industrial scale, all of which are in principle amenable to judicial interpretation, it would not have been entirely irrational to stipulate that these provisions be interpreted and applied 'in conformity with the relevant case law of the Court of Justice' without limitation of time. This was not the approach adopted in the Agreement. The UK courts, tribunals and administrative authorities must act 'in conformity with' any Court decisions handed down before 1 January 2021, but need only have 'due regard' to decisions handed down after that date, with the exception of Union provisions in the Protocols on Ireland and Cyprus where the 'conformity' obligation is maintained. ${ }^{90}$ Prima facie, the use of two different expression indicates that the Court's case law should have a different legal status depending on the date on which it was handed down.

The precise meaning of the term 'due regard' to Union law is unclear. It is used just twice in the Union Treaties, and on a small number of occasions in the Charter of Fundamental Rights. The third subparagraph of Article 6(1) TEU requires the Union's Charter rights, principles and freedoms to be interpreted 'with due regard to the explanations referred to in the Charter', an injunction which is repeated in Article 57(2) of the Charter. As these explanations are not binding - indeed, as 'explanations' they are not normative in character - it would not have been possible to require that the Charter be interpreted 'in conformity with' them. Article 171(2), second subparagraph, Euratom, requires that 'due regard' be paid to the Statutes of the Supply Agency in adopting the financial regulations which govern the Agency's revenue and expenditure. Given that the Statutes are set out in a binding legal act which devotes one of its three chapters to financial provisions, ${ }^{11}$ 'due regard' would appear to imply conformity with, rather than any lesser degree of respect for, the Statutes. The text of the Charter itself tells a similar tale. According to the preamble and Article 51, in its drafting the Charter pays 'due regard [to] the powers and tasks of the Union and for the principle of subsidiarity'; prima facie these powers and tasks, and this principle, are intended

\footnotetext{
${ }^{89}$ Declaration no. 17 annexed to the Final Act of the intergovernmental conference which adopted the Treaty of Lisbon.

${ }^{90}$ Respectively Art. 4(4) and (5) Withdrawal Agreement, Art. 13(2) Protocol on Ireland/ Northern Ireland, and Art. 1(2) Protocol on Cyprus.

${ }^{91}$ Council Decision 2008/114/EC, Euratom, establishing Statutes for the Euratom Supply Agency, OJ 2008 L 41/15.
} 
to impose a legally binding limit on the material scope of application of the Charter rights, freedoms and principles.

Outside the Treaties, 'due regard' appears to be used as a requirement to take account of relevant factual elements, rather than a vague invitation to consider whether a legal rule should be applied or not. By way of illustration, Article 204(3) of the EU-Ukraine Association Agreement provides for the simultaneous protection of homonymous geographical indications, provided each has been 'used in good faith and with due regard for local and traditional usage and the actual risk of confusion..$^{2}$ Similarly, in Union legislation, the General Data Protection Regulation, for example, requires producers of products using data processing to have 'due regard to the state of the art' when carrying out their duty to 'make sure controllers and processors are able to fulfil their data protection obligations' ${ }^{93}$ In carrying out her or his tasks, a data protection officer must 'have due regard to the risk associated with processing operations. ${ }^{94}$

From this brief survey, it appears that where Union law requires a decisionmaking authority to pay 'due regard' to a legally binding act, that authority is expected to act in conformity with the provisions of that act in so far as they are pertinent, whereas such conformity is either not required or not possible where 'due regard' is to be had to non-binding indications or to factual considerations.

From the UK side, two slightly different interpretations on the duty to 'have due regard' have been proposed. The Lords' European Union Committee suggested that 'the domestic courts would be under an obligation to take the case-law of the Court of Justice into account'; while not requiring that the case-law be followed on every occasion, the domestic court 'would usually require good reasons to depart from applying it. ${ }^{95}$ A 'reasons requirement' is a useful procedural rule, particularly in the administrative law context, but their Lordships do not provide any indication as to what reasons a UK court might legitimately rely on in refusing to follow a relevant decision of the Court of Justice.

The UK Attorney General has interpreted this phrase to mean that in some circumstances it may not be appropriate to apply a CJEU judgment ... bearing in mind that the provision in question will apply in the different context of the

\footnotetext{
${ }^{92}$ Art. 204(3), OJEU 2014 L 161/3, 29 May 2014.

${ }^{93}$ Para. 78 in the preamble to Parliament and Council Regulation (EU) 2016/679, OJ 2016 L $119 / 1$

${ }^{94}$ Ibid., Art. 39(2).

${ }^{95}$ Brexit: the Withdrawal Agreement and Political Declaration, 24 ${ }^{\text {th }}$ Report of Session 2017-2019, HL Paper 245, HMSO, 5 December 2018 ('Lords' 24 $4^{\text {th }}$ Report') para. 43, n. 47. The Committee published an updated version on 10 January 2020, which does not reproduce all the analysis of the previous report: Brexit: the revised Withdrawal Agreement and Political Declaration, $1^{\text {st }}$ Report of Session 2019-20, HL Paper 4, HMSO.
} 
Agreement', quoting the Court's judgment in Demirkan by way of support. ${ }^{96}$ In Demirkan, the Court was interpreting a provision of an international agreement by which the parties 'agree to be guided by' certain Treaty provisions on the free movement of persons when implementing the agreement. The Court read the term 'to be guided by' as indicating that the parties 'are not obliged to apply the [Treaty] provisions ... but simply to consider them as a source of guidance for the measures to be adopted in order to implement the objectives laid down in that agreement ${ }^{\text {' }}{ }^{97}$ Contrasting the 'essentially economic purpose' of the agreement with the wider objective of the Treaty to establish 'an area without internal borders', it denied the applicant the benefit of some of the jurisprudential developments of the Treaty provisions. Though he did not provide any further details, the Attorney General's approach would seem to indicate that UK courts would be entitled not to follow decisions of the Court which entailed a development of positive rights and obligations in the light of the wider objectives of the Treaty, rather than merely an interpretation of these in their own specific context.

While this may look like a more promising avenue for inquiry, the 'context' of the Withdrawal Agreement, which obtains for all Court decisions handed down after the end of the transition period, is the UK's leaving the EU legal order, and its desire to eliminate, or at least limit to the minimum, the influence within its territory of rulings of the Court of Justice. By that token, there is the risk that 'due regard' for the UK courts would consist in noting the existence of relevant caselaw of the Luxembourg court, but relying on the withdrawal context as a reason for not giving effect to that case law. A less hard-line approach would depend on the UK courts distinguishing between evolutionary and static judgments of the Court of Justice, rejecting the first and following the second. Such an evaluation would require an extensive knowledge and a subtle understanding of Union law, and an interpretation of the Court's case law, such as few would be as well qualified to provide as the Court of Justice. More generally, it is hard to see in the abstract how this context would distinguish situations in which the UK courts would follow the Court's case law from those in which they would not.

If 'due regard' means that a national court may choose not to comply with a ruling on a specific point of interpretation by the Court of Justice, it would follow that the same provisions may be given a different interpretation on either side of the Channel. This would contravene a number of other provisions and stated objectives of the Agreement. If a UK court does not comply with a ruling of the Court of Justice interpreting, for example, a provision of Directive 2004/38 which applies under Part Two of the Agreement, then that provision will not

\footnotetext{
${ }^{96}$ Para. 11, EU Exit - Legal position on the Withdrawal Agreement, Cm 9747; ECJ 24 September 2013, Case C-221/11, Demirkan, EU:C:2013:583, paras. 44-49.

${ }^{97}$ Demirkan, ibid., para. 45.
} 
'produce in ... the United Kingdom the same legal effects as those they produce within the Union', as it was intended to do by Article 4(1) of the Agreement. It would also undermine the reciprocal character of the protection of citizens' rights, to which the Agreement aspires according to its preamble. ${ }^{98}$ Moreover, Article 4(5) of the Agreement could also mean that the interpretation in the UK of a right under Part Two would depend on the hazard of which court has requested the ruling from the Court of Justice. Where the question is referred by a UK court any time within the next nine years or so, ${ }^{99}$ the UK courts would be bound to comply with the Court's ruling. Where the same question is referred to the Court of Justice by a court of a Member State, on the other hand, the UK courts will only be required to give the Court's ruling 'due regard', and hence could decide not to follow it.

The question cannot arise in practice until after the end of the transition period, and the Court may only be requested to provide an interpretation of Article 4(5) of the Agreement by a UK court, as this provision does not apply to the courts of the Member States. However, UK courts would then only be obliged to have 'due regard' to, rather than comply with, any ruling the Court of Justice were to provide interpreting the expression 'due regard'. Thus a provision which was intended to contribute to legal certainty may make 'confusion worse confounded'. ${ }^{100}$

\section{The Jurisdiction of the COURT Under the Withdrawal Agreement}

\section{'Taking back control of our laws'}

Ending the jurisdiction of the Court of Justice in the territory of the UK was one of the government's stated objectives in the Brexit process. It could be argued that this was added ex post facto, as the role or case law of the Court had not been debated widely or in detail during the referendum campaign. ${ }^{101}$ While this was described as a 'red line', in the end the government proved accommodating on certain matters, though not acceding to all the Union's demands in this area. The Court's jurisdiction in respect of the UK during the transition period is identical to that it enjoys with respect to a Member State. From 1 January 2021, its jurisdiction will cover pending cases, one category of 'new' cases - that is, those which

\footnotetext{
${ }^{98}$ Para. 6 in the preamble to the Withdrawal Agreement.

${ }^{99} \mathrm{See}$ 'New categories of jurisdiction' below.

${ }^{100}$ J. Milton, Paradise Lost (1667) ii, line 996.

${ }^{101}$ Brexit White Paper, supra n. 10, para. 2.3, p. 13, and Bradley, supra n. 29, section 4(b). By contrast, the Court's case law was debated in extraordinary detail in Ireland at the time of the second Lisbon Treaty referendum.
} 
are initiated after the end of transitional period - based on facts which occurred before the end of this period, and several new categories of cases. ${ }^{102}$

\section{Cases pending at the end of the transition period}

Maintaining the Court's jurisdiction for pending cases when the UK's withdrawal from the Union becomes fully effective was clearly the most sensible solution both in terms of efficiency - the Court is already seised of the dispute and can almost certainly provide a speedier solution - and justice, in that the law which applied to the facts of the case when they occurred was Union law as interpreted by the Court of Justice.

The Agreement confers on the Court jurisdiction to decide, before or after the end of the transition period, any case which has been commenced before 1 January 2021, including direct actions by or against the UK, that is, essentially annulment actions initiated by the UK and infringement and enforcement actions against it. ${ }^{103}$ The latter represents a concession by the UK, which at one point had suggested that the continuance of 'cases ... aimed at incentivising compliance with EU law when EU laws will no longer apply in the UK' might be superfluous. ${ }^{104}$

The Court's jurisdiction extends to appeals brought after the transition period against a decision of the General Court, and proceedings before the General Court where a matter has been remitted to it after an appeal, in cases originally commenced before the end of the transition period, as well as other forms of proceeding, such as a request for an Opinion on an international agreement the Union envisages to conclude, though this last may be considered unlikely. The Court also has jurisdiction to provide preliminary rulings on requests from UK courts which are referred to it before the end of the transition period. ${ }^{105}$ For this provision to have any useful effect, these courts must be entitled to refer questions to the Court of Justice after Brexit day; this was not the case under the European Union (Withdrawal) Act 2018 as originally adopted, which prohibited UK courts from referring such questions to the Court of Justice. This provision has subsequently been amended by the European Union (Withdrawal Agreement) Act 2020. ${ }^{106}$ During the transition period, these courts are under the standard obligations laid down by Article 267 TFEU. ${ }^{107}$

\footnotetext{
${ }^{102}$ In each case, 'old' and 'new' refer to the end of the transition period, rather than Brexit day, unless the contrary is specified.

${ }^{103}$ Art. 86(1) Withdrawal Agreement.

${ }^{104}$ H.M. Government, supra n. 78 , para. $12,3^{\text {rd }}$ indent, 3.

${ }^{105}$ Art. 86(2) Withdrawal Agreement; see, for example, Case C-168/20, MH and LA, pending.

${ }^{106}$ S. 6(1)(b) of the 2018 Act, as amended.

${ }^{107}$ Art. 127(1) Withdrawal Agreement.
} 
The essential complement to the Court's jurisdiction is, of course, the obligation on the UK to give binding force to the Court's rulings, both those handed down after Brexit day but before 1 January 2021, and those handed down after this latter date in pending cases. ${ }^{108}$ While the UK is explicitly required to comply with a Court judgment finding it is in infringement of its obligations, the enforcement mechanisms of Articles 260(2) and (3) TFEU allowing the imposition of financial sanctions are not applicable; this situation will fall instead within the dispute settlement procedure. ${ }^{109}$

\section{New cases based on old facts}

The maintenance of the possibility of initiating infringement actions against the UK was seen as an important safeguard against its benefiting from effective impunity in respect of its actions in the long period from deciding to withdraw and actually leaving the Union.

Under the Agreement, the Court will have jurisdiction in respect of new infringement actions, and State aid proceedings, against the UK based on old facts, that is, facts which occurred before 1 January 2021, where the proceedings are initiated within four years of that date. ${ }^{110}$ The alleged infringement may concern obligations under either the Treaties or the provisions of the Agreement concerning the transition period itself; only the Commission, and not the Member States, may initiate such proceedings. The Commission may also initiate infringement proceedings for the UK's failure to comply with any decision adopted in administrative procedures before the end of the transition period, or which were commenced before that date but only completed subsequently; these proceedings must be initiated within four years of the date of the decision. ${ }^{111}$ The decisions of the Court of Justice in such new infringement actions would also 'have binding force in their entirety on and in the United Kingdom'. The same is true of decisions addressed to the UK or companies or persons resident in the UK, which are adopted under ongoing administrative procedures. The Court would have exclusive competence to review these decisions. ${ }^{112}$

\section{New categories of jurisdiction}

The Agreement bestows 'new' jurisdiction on the Court of Justice in certain circumstances. This is not a novelty in international agreements concluded by the

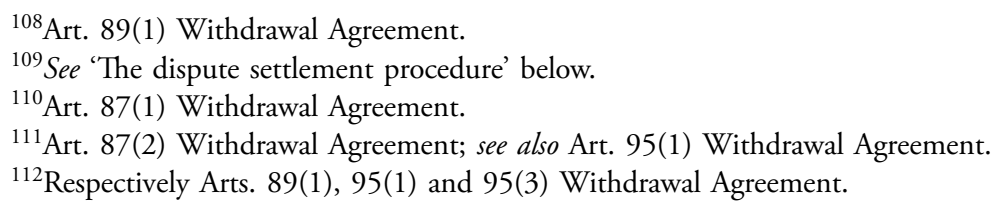


Union; the European Economic Area Agreement provides a well-known example. ${ }^{113}$

The most important new head of jurisdiction concerns requests for preliminary rulings on citizens' rights. The Court would be able to provide rulings on questions arising in any proceedings before the UK courts concerning Part Two of the Agreement which are commenced in these courts before 1 January 2029. The legal effects of any such rulings 'shall be the same as the legal effects of preliminary rulings' provided under the Treaty. ${ }^{114}$ The proper application in the UK of Part Two will also be subject to the supervision of an independent national authority with extensive powers to investigate and pursue alleged infringements by the UK authorities through the courts as need be. ${ }^{115}$

The Court will also be able to rule without limitation in time on infringement, enforcement, and preliminary ruling proceedings concerning the application and interpretation of the rules of the Agreement regarding the Union's own resources and the implementation by the UK of Union programmes. ${ }^{116}$ This is an integral part of the deal the negotiators reached on the so-called financial settlement, which had threatened to derail the negotiations on the Agreement even before they had got off the ground. In the end, wiser counsels prevailed. Other disputes on the financial settlement will fall to be dealt with under the dispute settlement procedure (see below).

The Protocol on Ireland/Northern Ireland applies large swathes of Union law to Northern Ireland. The jurisdiction of the Court is limited ratione materiae to the importation and placing on the market of goods in Northern Ireland, technical regulations, VAT and excise, the electricity market and State aid, and the Union's supervisory arrangements; within these limits, however, the usual panoply of jurisdictional clauses apply, with an explicit reference to the preliminary reference procedure. ${ }^{117}$ The Court also has jurisdiction under the Protocol on Cyprus. ${ }^{118}$

Finally, the special position of the UK as a newly departed ex-Member State is acknowledged by the invitation to the Court of Justice of the European Union to establish a 'regular dialogue' with the highest courts of the UK 'analogous to the dialogue in which the Court ... engages with the highest courts of the Member

${ }^{113}$ See ECJ 10 April 1992, Opinion 1/92, EEA Agreement II, EU:C:1992:189.

${ }^{114}$ Art. 158 Withdrawal Agreement.

${ }^{115}$ Art. 159 Withdrawal Agreement; see 'Special supervisory and enforcement regimes' below.

${ }^{116}$ Art. 160 Withdrawal Agreement.

${ }^{117}$ Art. 12(4), Protocol on Ireland/Northern Ireland to the Withdrawal Agreement.

${ }^{118}$ Art. 12, Protocol Relating to the Sovereign Base Areas of the United Kingdom of Great Britain and Northern Ireland in Cyprus. 
States. ${ }^{119}$ This dialogue is designed to facilitate the consistent interpretation of the Agreement in the two jurisdictions; while much of the Agreement is time-limited, the dialogue could prove useful well into the future, particularly if the future relations between the Union and the UK are settled through one or more agreement(s). ${ }^{120}$

\section{GOVERNANCE PROVISIONS}

\section{The Joint Committee and specialised committees: composition and functions}

The institution of a Joint Committee comprising representatives of the Contracting Parties is a standard feature of modern agreements between the Union and close trading partners, of which the EEA Joint Committee is the most familiar, and probably the most developed, example. ${ }^{121} \mathrm{~A}$ Joint Committee and six 'specialised committees' are established immediately on the entry into force of the Agreement, ${ }^{122}$ though most of the substantive provisions they will be charged with supervising only apply from the end of the transition period. ${ }^{123}$

The specialised committees each cover one of the principal substantive matters regulated by the Agreement: citizens' rights, 'separation provisions', the Protocols on Ireland/Northern Ireland, Cyprus, and Gibraltar, and the financial provisions. The Joint Committee, which meets at least once a year alternately in Brussels and in London, or by videoconference or teleconference, is to be co-chaired by a member of the European Commission and a minister of the UK government, while the specialised committees are co-chaired by representatives of the Union and the UK. ${ }^{124}$ The co-chairs of the Joint Committee may appoint 'high-level officials' as alternates, though the UK has already precluded in advance recourse to what seems an eminently sensible solution; similarly, though the Agreement permits the co-chairs to adopt decisions or recommendations by written procedure, the UK will have none of it. ${ }^{125}$

The Agreement does not lay down any rules regarding the numerical composition of the committees, but as the Agreement is concluded by the Union acting alone, the Union delegation will comprise Commission staff, without representatives

${ }^{119}$ Art. 163 Withdrawal Agreement.

${ }^{120}$ In practice, the Court already maintains a similar dialogue with supreme courts of a number of third States, including SCOTUS.

${ }^{121}$ Arts. 92-94, EEA Agreement, and Baudenbacher, supra n. 80.

${ }^{122}$ Arts. 164-166 Withdrawal Agreement.

${ }^{123}$ Art. $185,4^{\text {th }}$ para., Withdrawal Agreement.

${ }^{124}$ Rules of Procedure of the Joint Committee and Specialised Committees, Annex VIII to the Agreement.

${ }^{125}$ Ss. 15B and 15C, European Union (Withdrawal) Act 2018, as amended. 
of the Member State governments attending as of right. The committees may invite other persons 'in order to provide information on a particular subject; ; ${ }^{126}$ thus, representatives of Ireland, Cyprus and Spain may request to attend the relevant committee meetings dealing with specific issues under the Protocols regarding Ireland/ Northern Ireland, Cyprus and Gibraltar respectively. ${ }^{127}$ Except where the co-chairs decide otherwise, the Committee's meeting are confidential, though the provisional agendas and summaries of the minutes may, again at the choice of the co-chairs, be rendered public. ${ }^{128}$ While the Agreement provides that each of the parties may decide separately on the publication of the Committee's decisions and recommendations, it is difficult to see how the Union, which is bound to 'conduct [its] work as openly as possible, ${ }^{129}$ could avoid publishing these.

Unlike the EEA Agreement, the Withdrawal Agreement does not provide for any parliamentary component in the structures for post-Brexit relations between the Union and the UK, except for the very specific role of the Northern Ireland Assembly under the relevant Protocol. ${ }^{130}$ On the eve of exit day, the European Parliament called for joint scrutiny with the Westminster Parliament of the implementation and application of Part Two of the Agreement. ${ }^{131}$

\section{Duties and powers of the Joint Committee}

The Joint Committee has a general duty to supervise 'the implementation and application of th[e] Agreement' and has been vested with a range of quite farreaching powers to this end. ${ }^{132}$ Its decisions 'shall have the same legal effect as th[e] Agreement', and must be implemented by the parties. ${ }^{133}$ Thus, for example, it decides on the tasks of the specialised committees and supervises their work; it may subsequently change their tasks, dissolve any of the specialised committees,

\footnotetext{
${ }^{126}$ Rule 3(2), Rules of Procedure, supra n. 124.

${ }^{127}$ Art. 2(1), Council Decision (EU) 2020/135 on the conclusion of the Withdrawal Agreement, OJEU 2020 L 29/1.

${ }^{128}$ Respectively Rules 10(1), 7(3) and 8(5), Rules of Procedure supra n. 124.

${ }^{129}$ Art. 15(1) TFEU; on the link between open government and legitimacy, see General Court 22 March 2018, Case T-540/15, De Capitani v European Parliament, EU:T:2018:167, esp. para. 78.

${ }^{130}$ Art. 18(2), Protocol on Ireland/Northern Ireland, and the Declaration of the United Kingdom government on 'Democratic consent in Northern Ireland', 〈assets.publishing.service.gov.uk/ government/uploads/system/uploads/attachment_data/file/840232/

Unilateral_Declaration_on_Consent.pdf), visited 13 October 2020.

${ }^{131}$ Resolution of 15 January 2020 on implementing and monitoring the provisions on citizens' rights in the Withdrawal Agreement, P9_TA(2020)0006, para. 22.

${ }^{132}$ Art. 164(3) Withdrawal Agreement.

${ }^{133}$ Art. 166(2) Withdrawal Agreement.
} 
and/or establish new ones. ${ }^{134}$ For four years from the end of the transition period, the Committee is entitled to correct errors, address omissions and 'address situations unforeseen when th[e] Agreement was signed', though excluding the common and institutional provisions and those on the transition period; in exercising this power, the Committee may not, however, modify the 'essential elements' of the Agreement. ${ }^{135}$ This last is a term of art in Union law; it is used in particular as a criterion to identify the hard core of regulatory competence which the Union legislature may not delegate to the Commission, compliance with which is amenable to judicial review in this context. ${ }^{136}$

The normative powers of the Joint Committee do not end there. It enjoys a discretion as to whether the relevant provisions of the Agreement should be aligned with modifications of the Union's principal regulations on social security matters adopted after the end of the transition period. Under the Ireland Protocol, it adopts a number of regulatory measures, such as the criteria to determine whether a good imported into Northern Ireland from outside the Union is at risk of subsequently being moved into the Union', and the conditions under which certain fishery and aquaculture products may be exempted from duties. Along with its powers regarding substantive matters, the Joint Committee has certain institutional competences, such as keeping under 'constant review' the functioning of the dispute settlement procedure (in which it also plays a role; see 'The dispute settlement procedure' below), and amending as need be its rules of procedure and those of the specialised committees, as well as the Code of Conduct for members of the arbitration panels. In certain financial matters, the Joint Committee plays the role of an arbitrator, for example where the Union presents the UK with a bill for access to certain networks, information systems and databases in an amount which is larger than the estimation. ${ }^{137}$ Unlike the equivalent body in the EEA legal system, the Joint Committee is not charged with keeping under review the development of the relevant case law of the Court of Justice or the UK courts. ${ }^{138}$

\footnotetext{
${ }^{134}$ Arts. 166(4)(b), (5)(c), and (5)(b) Withdrawal Agreement.

${ }^{135}$ Art. 166(5)(d) Withdrawal Agreement; see e.g. Joint Committee Decision 1/2020 of 12 June 2020, 〈assets.publishing.service.gov.uk/government/uploads/system/uploads/attachment_data/file/900242/ TS_9.2020_Decision_of_Joint_Committee_amending_Agreement_on_withdrawal_of_UK_ from_EU_and_EAEC.pdf $\rangle$, visited 13 October 2020.

${ }^{136}$ Art. 290(1) TFEU and ECJ 5 September 2012, Case C-355/10, European Parliament v Council, EU:C:2012:516; for a brief overview, see Bradley, supra n. 69, section 7, 126, and case study 5.2, 141-142.

${ }^{137}$ See, for example, Art. 50 Withdrawal Agreement (access to networks, information systems, and databases on customs procedures).

${ }^{138}$ Art. 105(2) EEA Agreement.
} 
Perhaps the single most important power of the Joint Committee is that to extend the transition period. As noted elsewhere, the UK government closed off this possibility before the Agreement was even signed. It is difficult to square this preemptive decision with the duty incumbent on both parties to 'refrain from any measure which could jeopardise the attainment of the objectives of the Agreement' under Article 5, second paragraph; at the time it adopted its decision, the UK could not have known whether or not it was jeopardising the attainment of the Agreement's objectives.

The House of Lords European Union Committee has concluded that ' $[\mathrm{t}] \mathrm{he}$ Joint Committee will be critical in ensuring the smooth working of the Withdrawal Agreement. It will be a uniquely powerful and influential body'; their Lordships also expressed concern that the Joint Committee's power of amendment is so widely drawn and the fact that its functioning is 'not subject to clear scrutiny procedures or parliamentary oversight'. ${ }^{139}$

\section{Supervision, ENFORCEMENT, AND DISPUTE SETTLEMENT}

\section{The Union's position: citizens' defence}

In withdrawing from the Union, the UK said goodbye not only to its material rights and obligations under the Treaty, ${ }^{140}$ but also to a legal order which boasts a formidable array of mostly judicialised mechanisms to ensure those rights and obligations are observed of a range and intensity which is unprecedented in international relations. These include the proactive supervision of the respect by Member States of their obligations by a wholly autonomous institution, backed by possible infringement and enforcement proceedings before the Court, which can result in the imposition of periodic penalty payments and/ or lump sum fines. This accountability is complemented by the possibility for individuals and businesses to rely directly on Union law provisions in the national courts, and to claim damages against the State and its organs, including the courts, for failure properly to apply Union law. As a result of these mechanisms, the standard remedy in international law of disputes between States, while possible, ${ }^{141}$ was rarely used until quite recent times.

The Union was aware that the Brexit referendum was won in part on the promise of reducing immigration from the EU to the UK, along with some

${ }^{139}$ Lords' $24^{\text {th }}$ Report, supra n. 95, paras. 35 and 36, p. 11 and 12.

${ }^{140}$ Where it can show the necessary locus standi, the UK will still be entitled to take proceedings in direct actions in the same way as any other third State; see e.g. ECJ 7 March 2013, Case C-547/10 P, Swiss Confederation v European Commission, EU:C:2013:139.

${ }^{141}$ Arts. 259 and 273 TFEU; see also Art. 344 TFEU. 
meretricious claims regarding a putative post-Brexit windfall for the National Health Service to be paid for from the saving of the UK's contribution to the Union budget. As noted above, doubt was cast in UK circles on both the existence and the possible enforcement of any financial obligations towards the Union, while internal disagreements regarding the Ireland/Northern Ireland Protocol had delayed the conclusion of the Withdrawal Agreement by more than a year. ${ }^{142}$ In these circumstances, it is little wonder the Union had major concerns as regards the proper application of the Agreement by the UK.

The Union's opening position could be described as rather defensive of the role of the Court of Justice. For citizens' rights, the continued application of Union law, and provisions of the Agreement closely related to Union law, such as the financial settlement, it advocated that the Court should have jurisdiction. For other provisions of the Agreement, the Union would only accept 'an alternative dispute settlement ... if it offers equivalent guarantees of independence and impartiality to the Court of Justice of the European Union'. ${ }^{143}$ The negotiators' draft agreement of 19 March 2018 provided for compulsory jurisdiction for the Court in any dispute not settled by the Joint Committee within three months, as well as jurisdiction to review compliance with its judgments on such disputes, though this was part of the text on which the negotiators had not reached agreement. ${ }^{144}$

\section{The UK position: the 'Moldova moment'}

For its part, the UK failed to provide, at least in its published statements of position, specific proposals on supervision, enforcement, and dispute settlement, beyond affirming in the Brexit White Paper that '[a]ny arrangements must be ones that respect UK sovereignty, protect the role of our courts and maximise legal certainty, including for businesses, consumers, workers and other citizens.' ${ }^{145}$ The White Paper also provided thumbnail sketches of examples of existing dispute settlement mechanisms: CETA, the EU-Switzerland bilateral arrangements, NAFTA, Mercosur, the New Zealand-Korea Free Trade Agreement, and the WTO. The government clarified its thinking some six months later, when negotiations were under way; in particular, it took the view that 'one common feature of most international agreements, including all agreements between the EU and a third country, is that the courts of one party are not given direct jurisdiction over

\footnotetext{
${ }^{142}$ See e.g. Dougan, supra n. 18, p. 676-689.

${ }^{143}$ Council negotiating directives, XT 21016/17, 22 May 2017, para. 42, p. 17.

${ }^{144}$ Arts $162(4)$ and 163(1), 〈ec.europa.eu/commission/sites/beta-political/files/draft_agreement_ coloured.pdf $\rangle$, visited 13 October 2020.

${ }^{145}$ Supra n. 10, para. 2.10 .
} 
the other in order to resolve disputes between them'. ${ }^{146}$ It also acknowledged, however, that ' $[\mathrm{i}] \mathrm{n}$ agreements which utilise concepts of EU law ... an approach which has been adopted is a reference for a [binding] interpretation to the CJEU', citing Article 403 of the EU-Moldova Association Agreement as an example. ${ }^{147}$ In a previous 'position paper' published just a month or so before, it had 'made it clear that leaving the EU will end the jurisdiction of the CJEU in the UK'. ${ }^{148}$ The UK's 'Moldova moment', adding the qualifier 'direct' before 'jurisdiction', was therefore seen as a breakthrough, and indeed the dispute settlement mechanism eventually agreed upon borrows from the Moldova model.

\section{Special supervisory and enforcement regimes}

The primary responsibility for supervising the implementation and application of the Agreement falls on the Joint Committee. ${ }^{149}$ However, to supervise the application in the UK of Part Two (citizens' rights), the Agreement foresees the establishment of an independent monitoring authority empowered to 'conduct inquiries on its own initiative', to receive complaints, and to bring legal proceedings as need be in the courts of the UK. Both the Authority and the Commission report back annually to the specialised committee on citizens' rights; the Joint Committee is to carry out an assessment of the functioning of the Authority after 31 December 2028, on the basis of which the Joint Committee may 'decide in good faith' that the UK may abolish the Authority. ${ }^{150}$ Given the bilateral character of the Agreement, unlike the EEA Agreement, it was only to be expected that responsibility for the supervision of Part Two be vested in a UK body of some kind, rather than a supranational surveillance authority.

While the UK authorities are also primarily responsible for the implementation of the Ireland Protocol, special supervisory arrangements nonetheless obtain in this domain. Compliance with certain provisions will remain indefinitely subject to the direct supervision of the Commission and the Court of Justice of the European Union. ${ }^{151}$ More generally, 'Union representatives shall have the right to be present during any activities of the authorities of the United Kingdom related to the implementation and application of provisions of Union law made applicable by th[e] Protocol', as well as the inspection of goods brought into Northern

\footnotetext{
${ }^{146}$ Enforcement and dispute resolution, Future Partnership paper (undated; August 2017) para. 29, p. 6.

${ }^{147}$ Ibid., paras. 57 and 58, p. 10.

${ }^{148}$ H.M. Government, supra n. 78 , para. 10, p. 3.

${ }^{149}$ Art. 164(3) Withdrawal Agreement; see 'Supervision, enforcement, and dispute settlement' below.

${ }^{150}$ Art. 159 Withdrawal Agreement.

${ }^{151}$ See 'The jurisdiction of the court under the Withdrawal Agreement' supra.
} 
Ireland from any other part of the UK in order to ascertain whether there is a risk that the goods will subsequently be transported into the Union territory, for example, by crossing the Irish border. ${ }^{152}$

\section{The dispute settlement procedure}

The Agreement sets out a detailed procedure for dispute settlement which will apply, to the exclusion of any other procedure, from the end of the transition period. While this has been described as 'broadly similar to the dispute settlement rules of the World Trade Organisation', ${ }^{153}$ that is true only of its the basic framework and the fact that it is reserved to persons under international law rather than individuals. Certain of its provisions are strikingly different, though in the end an unresolved dispute could lead to the suspension of obligations as under the WTO Agreements.

The relevant provisions and procedure set out at Articles 167 to 179 of the Agreement, may be schematised thus:

- obligation on the parties 'at all time to endeavour to agree on the interpretation and application of th[e] Agreement and ... arrive at a mutually satisfactory resolution of any matter that might affect its operation';

- obligation to engage in consultations within the Joint Committee;

- in the absence of a 'mutually agreed solution' within three months, initiation of arbitration procedure at the suit of either party;

- where the dispute raises questions of interpretation of 'a concept of Union law' or of a provision of Union law referred to in the Agreement, or concerns the compliance by the UK with a Court of Justice judgment finding it has failed to comply with an obligation under the EU Treaties or the Agreement itself, the arbitration panel 'shall not decide on any such question' but instead request the Court of Justice to give a ruling, which is binding on the arbitration panel;

- the panel provides its ruling within 12 months, though either party may request urgent consideration; the ruling is binding on the parties, who are required to 'take any measure necessary to comply in good faith' and to agree on a time limit for compliance;

- where the parties disagree on the time limit, the arbitration panel fixes 'a reasonable time for compliance';

- the panel is also competent to review the compliance measure, as need be requesting the Court of Justice to rule on any relevant question of Union law;

- in case of non-compliance, the panel may order the respondent to pay a lump sum or make a penalty payment to the complainant, the amount of which

${ }^{152}$ Art. 12(2), Protocol on Ireland/Northern Ireland.

${ }^{153}$ S. Peers, EU Law Analysis, 18 October 2019, (eulawanalysis.blogspot.com/2019/10/analysis3-of-revised-brexit-withdrawal.html〉. 
reflects the seriousness and duration of the non-compliance with both the underlying obligation and the panel's ruling;

- where the respondent has either failed to comply with a panel ruling or to pay over the sums ordered, the complainant may suspend its obligations under the Agreement except for Part Two (or equivalent provisions in other agreements between the Union and the UK);

- the respondent may challenge before the panel the proportionate character of the complainant's suspension decision;

- the panel may also rule on whether the respondent's measure of compliance brings it into line with its obligations under the Agreement.

The establishment, composition and functioning of the Brexit arbitration panel is based on the Union's practice in bilateral trade and trade-plus agreements. Before 1 January 2021 the parties are to establish a tripartite list of 25 arbitrators; two lists of ten ordinary members each to be proposed by the Union and the UK, and a list of five chairpersons proposed jointly. ${ }^{154}$ The qualifications for appointment as an arbitrator are those required for appointment to the Court of Justice, that is, independence beyond doubt and either the qualifications for appointment to the highest judicial office in their home countries, or the status of a 'jurisconsult of recognised competence'; arbitrators must, moreover, possess 'specialised knowledge or experience of Union law and public international law'. ${ }^{155}$ Members or staff of the Union institutions, and of the governments of the Member States and the UK, are disqualified from appointment as arbitrators; on the other hand, neither Union citizens nor British nationals are precluded from serving on a panel, as they would be under the WTO system, and the parties have no right to object to each other's panellists, even 'for compelling reasons'. ${ }^{156}$

For each individual dispute a panel of five members is established, two each from the parties' lists, and a chairman selected by the four members from the joint list of chairpersons; the Agreement also provides arrangements for the selection of a chairperson, or even of a panel, where the primary arrangements fail to operate. ${ }^{157}$ Though encouraged to act by consensus, the arbitration panel has an important tie-breaking function, and may decide by majority vote; no dissenting opinion may be published. ${ }^{158}$

While the preliminary ruling scheme of Article 174 of the Agreement has clearly been designed to safeguard the Court's monopoly on the authentic interpretation of provisions of Union law, its compatibility with Union law has been

${ }^{154}$ Art. 171(1) Withdrawal Agreement.

${ }^{155}$ Art. 171(2) Withdrawal Agreement.

${ }^{156}$ Respectively Art. 171(2) Withdrawal Agreement, and Art. 8(3) and (6), WTO Dispute Settlement Understanding, Annex 2 to the WTO Agreement.

${ }^{157}$ Art. 171(5), $2^{\text {nd }}$ para., (6), (8) and (9) Withdrawal Agreement.

${ }^{158}$ Art. 180(1) Withdrawal Agreement. 
questioned on the grounds that the procedure allows the arbitration panel to determine at first instance whether the dispute before it raises a question of Union law which requires a ruling from the Court. ${ }^{159}$

No difficulty can arise if the panel should erroneously refer a question to Luxembourg; as the conditions laid down in Article 174 of the Agreement would not be fulfilled, the Court would be obliged simply to refuse jurisdiction. The putative threat to the autonomy of the Union's legal order would presumably ensue if, conversely, the panel refused to refer to the Court a question of Union law, and proceeded to rule on the matter itself; the ruling would in principle be binding on the Union, including on the Court itself. ${ }^{160}$ However, in so doing, the arbitration panel would be acting in manifest breach of Article 174(1) of the Agreement, which leaves it no discretion as to whether or not it should refer a question of interpretation of Union law to the Court: 'the arbitration panel shall not decide on any such question. In such a case, it shall request the Court of Justice ... to give a ruling'. It would be anomalous indeed if the Court were to find that it was bound by a panel ruling which had been adopted in manifest breach of Union law, or held the Union institutions to such a ruling. That said, the Agreement does not provide for any judicial or political review of rulings of an arbitration panel, and the only discernible solution would be for the parties to go back to the Joint Committee again.

\section{Conclusions}

The political context in which the Withdrawal Agreement was negotiated was distinctly less than propitious for a number of reasons. Chief amongst these were the professed insouciance of the UK government as regards the desirability of concluding a deal in the first place, and the pervading political instability, which saw three Prime Ministers, three Secretaries of State for Exiting the European Union, and two general elections, in the three and a half years from referendum to Agreement, to say nothing of a divided minority government facing a divided opposition in the House of Commons. The government's handling of the withdrawal process, which also included an attempt to by-pass Parliament in launching the procedure, and the illegal prorogation of Parliament just when it would have been required by law to scrutinise the text of a withdrawal agreement, ${ }^{161}$ was more 'Fawlty Towers' than 'Yes, Minister'. It prompted The Economist to bemoan

${ }^{159} \mathrm{~T}$ Lock, 'On Thin Ice: The Role of the Court of Justice under the Withdrawal Agreement', Verfassungsblog, 15 November 2018; N Lavranos, 'The potential incompatibility of the arbitration clause in the Brexit withdrawal agreement', Arbitration Blog, 6 December 2018.

${ }^{160}$ Art. 180(2) Withdrawal Agreement.

${ }^{161}$ Respectively Miller I, supra n. 23, and R (Miller) v The Prime Minister [2019] UKSC 41. 
that Brexit was the 'mother of all messes', and another commentator to suggest that 'Brexit rather dented the UK's reputation for stable and competent government'. ${ }^{162}$

For all that, the Union did not have the luxury of walking away from the negotiating table, or threatening to do so. The launching of the Brexit process, following a decision over which it had had no useful influence, was an existential moment for the Union, where it had to fall back on its values, beyond the comforting principles and rules of the Treaties. Its reaction, as reflected notably in the European Council Guidelines of 29 April 2017, was balanced and defensive, not vindictive and aggressive, and relied on the unity and solidarity of the Member States in order to get 'a result that is fair and equitable for all Member States and in the interests of [the Union's] citizens'. ${ }^{163}$ The Union set out with a game plan ('people, money, Ireland') and a modus operandi, a united front against a Disunited Kingdom, and stuck to these to an extent which surprised many on both sides.

The Withdrawal Agreement itself is something of an achievement, both technically and politically. Of course, it is technically pleasing to the legal eye largely because it borrows the familiar forms and structures of EU law whose efficiency has been demonstrated over the years. Politically, the Agreement is an achievement because of its very existence, which was uncertain right up until the early morning of 13 December 2019, when the UK general election results were in. Given the shared interest of the parties in an orderly withdrawal rather than probable chaos on several fronts (economic, legal and possibly even political), reaching an agreement could, and should, have been easier. While withdrawal from the Union may be an inconvenience and an added expense for businesses, ${ }^{164}$ it is potentially devastating psychologically and socially for the individuals concerned, a fact that would have allowed a withdrawing State to hold the EU citizens on its territory to ransom, were it so minded. That Article 50 TEU takes zero account of the interests and expectations of such individuals gives the lie to the Union's boast of almost sixty years ago that Treaty rights 'become part of their legal heritage'. ${ }^{165}$

\footnotetext{
${ }^{162}$ Respectively cover story, 17 January 2019, and Dougan, supra n. 18, p. 640, and sections 2.2 and 2.3 .

${ }^{163}$ Guidelines, supra n. $33,4^{\text {th }}$ para., p. 1

${ }^{164}$ The Court has long held, in effect, that the Union cannot guarantee the possibility to trade with third countries: ECJ 9 September 2008, Joined Cases C-120/06 and C-121/06, FIAMM and Fedon v Council and Commission, EU:C:2008:476, para. 186. No doubt this also applies to trade with a former Member State too.

${ }^{165}$ ECJ 5 February 1963, Case 26/62, Van Gend en Loos, EU:C:1963:1, $4^{\text {th }}$ para., p. 12.
} 
The Union needed a deal, but not a deal at any price. For all his 'dead in a ditch' diplomacy and 'diddley-squat' accountancy, ${ }^{166}$ in the end the UK government under Boris Johnson did not succumb to the siren calls of a no-deal Brexit, and met the Union part-way on most of its fundamental demands for a viable withdrawal settlement: agreeing to a method of calculating its payments to the Union budget, avoiding a hard border on the island of Ireland, respecting the autonomy of Union law, and continuing to act as if it were a Member State for the first 11 months of its new-won 'freedom' from the Union. Neither the provisions on citizens' rights, nor the scheme introduced by the UK in preparation for their coming fully into effect, have met with universal satisfaction, and it is only to be expected that both these provisions and other parts of the Agreement will give rise to problems in the future. The proper application of these provisions may in practice depend to a large extent on the willingness of the UK courts to trust the Court of Justice to provide a just solution to such problems.

The most important feature of the Withdrawal Agreement, however, is that it is itself only a transitional measure; it does not complete the withdrawal. For the UK, it provides a bridge from full membership of the Union to the status of a fully third State. For the Union, the Agreement mitigates the disruption and likely economic damage which follows from losing its then second largest economy. True, the provisions of the Ireland/Northern Ireland Protocol are intended to be permanent, and those on citizens' rights to last a lifetime. For the rest, however, the analgesic effects of the Agreement will soon wear off. It is uncertain at the time of writing what the next step in the relations between the Union and the UK will be, and whether for those matters not yet covered the Agreement has banished, or merely postponed, the prospect of a 'hard Brexit'.

\footnotetext{
${ }^{166}$ Boris Johnson, respectively West Yorkshire police recruits speech, 5 September 2019, (www. theguardian.com/politics/2019/sep/05/boris-johnson-rather-be-dead-in-ditch-than-agree-brexitextension $\rangle$ and evaluation of the draft financial provisions of the 2018 withdrawal agreement, 3 September 2018, 〈www.politico.eu/article/boris-johnson-uk-has-won-diddly-squat-in-brexittalks-eu/>, both visited 13 October 2020.
} 